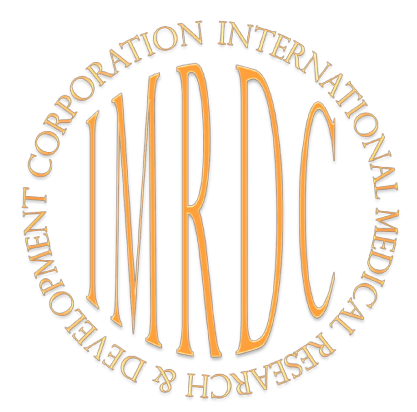

\title{
New Features of Molecular Diagnostics of Ulcerative Colitis
}

\author{
A.S. Volkov, $\mathrm{PhD}^{1}$; I.G. Stolyarova, $\mathrm{PhD}^{1}$; I.V. Sarvilina, $\mathrm{PhD}, \mathrm{ScD}^{2 *}$ \\ ${ }^{1}$ Rostov-on-Don State Medical University, Rostov-on-Don, Russian Federation \\ ${ }^{2}$ Medical Centre "Novomeditsina", Rostov-on-Don, Russian Federation
}

\begin{abstract}
The purpose of this study was to search for new molecular markers for the diagnosis of ulcerative colitis (UC). The study included 65 patients (range from 22 to 35 years, 24 men and 41 women) with left-sided UC (Montréal classification), mild and moderate activity, infrequent $(\leq 1 /$ year) relapses according to the inclusion/exclusion criteria in the research. Criteria of the diagnosis of UC corresponded to ECCO Consensus. The duration of UC was 5.3 years. The control group included 30 healthy individuals. Molecular phenotyping of colon mucosa was processed with methods of proteomics. The data of the molecular interactions were received with STRING 10.0 database. Potentially new molecular markers of the development of UC were identified. (Int J Biomed. 2016; 6(1):70-73.).
\end{abstract}

Keywords: ulcerative colitis; colon mucosa; proteomics; diagnostic markers.

\section{Introduction}

The worldwide incidence rate of ulcerative colitis (UC) varies between 0.5 and 24.5 cases per 100,000 persons. Currently, the incidence of UC in Russia is $5-30$ cases per 100,000 per year. The peak age of onset for UC is most common between 15 and 30 years, although it may occur at any age. About $10 \%$ of the cases occur in individuals under the age of 18 . UC is slightly more common in males $[1,2]$.

$\mathrm{UC}$ is characterized by an even and continuous distribution of the inflammatory infiltrate that only affects the lamina propria. Furthermore, the disruption of normal crypt architecture and the presence of crypt abscesses are the main histological characteristics of UC. UC patients have a wellknown risk of colorectal cancer [3].

So far, mechanisms of UC remain to be fully understood and require a detailed multidisciplinary approach [4-6]. In 1990, an international consortium revealed universal genetic sequences which enable a genetic map of UC [7]. According to Medscape, methods of cell and molecular biology have shown the role of thrombocytosis (1966), antibodies to E.coli (1969), key components of the inflammation with UC using granulocytes labeled Indium-111 (1985), interleukin-6 (IL-6), tumor necrosis factor (TNF)- $\alpha$, pANCA, C-reactive protein (CRP) (1990), thrombocytes, sedimentation rate of erythrocytes in differential diagnosis between UC and

*Corresponding author: Irina V. Sarvilina, PhD, ScD. CEO of Medical Centre «Novomeditsina», Rostov-on-Don, Russia.E-mail: isarvilina@mail.ru infectious diarrhea (1991), IL-12 (1995), fecal lactoferrin (1996), the level of a4ß7-integrin in T-lymphocytes (1997), pANCA and ASCA (1998), bacterial antibodies and fecal calprotectin (1999), serum protein S100A12 $(2003,2006)$, and IL-23 in colon mucosa (2004).

Modern achievements of proteomic methods of analysis are ideal for research that is free from hypotheses and allows us to define molecular characteristics of inflammation in colon mucosa of UC patients.

\section{Material and Methods}

The study conducted in accordance with WMA Declaration of Helsinki (1964-2013) and the permission of the Ethics Committee of the Rostov-on-Don State Medical University (Rostov-on-Don, Russia).

The study was prospective comparative cohort with parallel design and included 65 patients (range from 22 to 35 years, 24 men and 41 women) with left-sided UC (Montréal classification) [8], mild and moderate activity (Truelove - Witts' criteria, Mayo score) [9,10], infrequent $(\leq 1 /$ year $)$ relapses according to the inclusion/exclusion criteria in the research. Criteria of the diagnosis of UC corresponded to ECCO Consensus [11]. The duration of UC was 5.3 years. The induction of UC remission assumed the acceptance of mesalazine 3 to $4 \mathrm{~g} /$ day p.o. and rectally 1 to $2 \mathrm{~g} /$ day; the maintenance of UC remission included the acceptance of mesalazine $1.5 \mathrm{~g} /$ day p.o. for 3 years by patients with intolerant UC. The duration of therapy was 4.6 years. The control group included 30 healthy individuals. 
At the stage of data collection and screening, we applied standard methods for identification of UC: the assessment of the patient's symptoms, risk factors, medical history, physical examination, complete blood count, erythrocyte sedimentation rate (ESR) (Advia 120, Bayer Diagnostics, Germany), biochemical analysis of blood and urine, serological markers perinuclear anti-neutrophil cytoplasmic antibodies (pANCA) and anti-Saccharomyces cerevisiae antibodies (ASCA) (ELISA, Siemens 2000, Germany), faecal calprotectin (ELISA, Buhlmann, Швейцария), the stool culture (culturedependent methods, DNA-PCR and FISH analysis), patient's immunization status to various viral diseases and tuberculosis status.

Biosamples of colon mucosa (3-10mg) in patients with $\mathrm{UC}$ in the active stage and in healthy persons were received by ileocolonoscopy (Olympus, Japan) with colon mucosa biopsy (Rachmilewitz index). We used endoscopic scoring by the Schroeder classification for UC and Endoscopic Index of Severity (UCEIS) [12,13]. Histological characteristics of colon mucosa in UC in the active stage were performed by lightmicroscopy (architectural features, epithelial abnormalities, and inflammatory features).

The storage of biosamples before proteomic analysis was carried out at $-80^{\circ} \mathrm{C}$. Sample preparation was conducted as follows: biosamples were homogenized and processed by lysis buffer (1mg bioptate/10 $\mu$ l lysis buffer, $\mathrm{pH} 3-10$, GE Healthcare, Sweden), CHAPS (Applichem, Germany), and $1 \%$ DTE (Sigma-Aldrich D8255) in water. After the incubation during $2 \mathrm{~h}$ at room temperature, lysed cells were centrifuged at $10000 \mathrm{RPM}$ for $20 \mathrm{~min}$ at $4{ }^{\circ} \mathrm{C}$.

The separation of individual proteins of colon mucosa was based on technologies of IEF, SDS-PAGE, 2DPAGE, by standard sets (MB-HIC C8 Kit, MB-IMAC Cu, MB-Wax Kit, «Bruker», USA). Automated mass spectrometry imaging was performed by matrix-assisted laser desorption-ionization timeof-flight mass spectrometry (MALDI-TOF-MS/MS, Ultraflex II, «Bruker», USA). The partially identified sequences were then submitted to "BLAST protein-protein" and screened against the Homo sapiens Swissprot database to check if this identification matched the MASCOT-identification (Matrix Science, UK). The data of the molecular interactions and functional features of proteins were received with STRING 10.0 database.

Based on the data of standard methods of identification of UC and molecular phenotyping of colon mucosa we conducted new prognostic markers, molecular pathways of $\mathrm{UC}$ and diagnostic tests in patients with UC.

Statistical analysis of the survey data was performed using the software "Statistica 12.0" (Statsoft, Russia). Baseline characteristics were summarized as frequencies and percentages for categorical variables and as mean \pm SEM for continuous variables. Student's unpaired paired t-tests were used to compare two groups for data with normal distribution. Group comparisons with respect to categorical variables are performed using chi-square tests with Yates correction or, alternatively, Fisher's exact test when expected cell counts were less than 5. A probability value of $P<0.05$ was considered statistically significant.

\section{Results}

Clinical-anamnestic and laboratory characteristics of UC patients are presented in Table 1.

Table 1.

Clinical-anamnestic and laboratory characteristics of UC patients

\begin{tabular}{|c|c|c|c|c|}
\hline \multirow[b]{2}{*}{ Variable } & \multicolumn{3}{|c|}{ Group patients with UC $(\mathrm{n}=65)$} & \multirow[b]{2}{*}{$\begin{array}{l}\text { Control } \\
\text { group } \\
\text { (d) }\end{array}$} \\
\hline & $\begin{array}{l}\text { Active } \\
\text { stage } \\
\text { (a) }\end{array}$ & \begin{tabular}{|c|}
$\begin{array}{c}\text { Remission } \\
\left(1^{\text {st }} \text { year }\right) \\
(b)\end{array}$ \\
\end{tabular} & $\begin{array}{c}\text { Remission } \\
\left(3^{\text {rd }} \text { year }\right) \\
(\mathrm{c})\end{array}$ & \\
\hline Sex (male/female), n & $39 / 26$ & $39 / 26$ & $39 / 26$ & $17 / 13$ \\
\hline Age, yrs & $29.2 \pm 2.5$ & $30.3 \pm 2.7$ & $32.1 \pm 2.9$ & $30.1 \pm 3.3$ \\
\hline Weight, kg & $58.3 \pm 1.7 *$ & $60.4 \pm 1.8 * *$ & $64.3 \pm 2.2$ & $69.7 \pm 2.3$ \\
\hline Height, $\mathrm{cm}$ & $171.2 \pm 1.7$ & $169.4 \pm 1.6$ & $170.5 \pm 1.6$ & $170.2 \pm 1.7$ \\
\hline BMI, $\mathrm{kg} / \mathrm{m}^{2}$ & $19.9 \pm 1.3$ & $21.2 \pm 1.6$ & $22.3 \pm 1.9$ & $25.8 \pm 2.1$ \\
\hline UC duration,yrs & $4.2 \pm 1.1$ & $4.0 \pm 1.0$ & $4.4 \pm 1.1$ & - \\
\hline $\begin{array}{l}\text { UC activity: } \\
\text { mild } \\
\text { moderate }\end{array}$ & $\begin{array}{l}39 \\
26\end{array}$ & $\begin{array}{l}52 \\
13\end{array}$ & $\begin{array}{c}65 \\
-\end{array}$ & - \\
\hline $\begin{array}{l}\text { Mayo score: } \\
1 \\
2 \\
\end{array}$ & $\begin{array}{l}39 \\
26\end{array}$ & $\begin{array}{l}52 \\
13\end{array}$ & $\begin{array}{c}65 \\
- \\
\end{array}$ & - \\
\hline Weight loss, $\mathrm{n}$ & 65 & 57 & 43 & - \\
\hline Anemia, $\mathrm{n}$ & 65 & 52 & 33 & \\
\hline Arthralgia, $\mathrm{n}$ & 29 & 9 & 9 & - \\
\hline Erythema nodosum, $\mathrm{n}$ & 14 & 9 & 9 & - \\
\hline \multicolumn{5}{|c|}{ Laboratory parameters } \\
\hline $\mathrm{pANCA}(>1: 40), \mathrm{n}$ & 65 & 57 & 45 & - \\
\hline ASCA, RU/ml & $35.4 \pm 3.2$ & $18.9 \pm 2.6$ & $19.2 \pm 2.7$ & - \\
\hline $\begin{array}{l}\text { Faecal } \\
\text { calprotectin, } \mu \mathrm{g} / \mathrm{g}\end{array}$ & $234.5 \pm 9.3^{\wedge}$ & $186.8 \pm 8.4^{\wedge}$ & $145.3 \pm 7.1^{\wedge}$ & $32.4 \pm 3.1$ \\
\hline
\end{tabular}

* $-P=0.004$ between (a) - (d); ** $-P=0.029$ between $(b)-(d)$; $\wedge-P=0.000$ between $(a)-(d),(b)-(d)$, and $(c)-(d)$.

Results of ileocolonoscopy with biopsy and histological characteristics of UC are shown in Table 2. Parameters of complete blood count, ESR, serum urea, creatinine, electrolytes, liver enzymes, serum iron levels, CRP were changed in active stage of UC: high platelet count $(n=32)$, elevated ESR $(\mathrm{n}=65)$, hypokalemia $(\mathrm{n}=35)$, hypomagnesemia $(n=32)$, elevated level of CRP $(n=65)$, elevated level of serum urea and creatinine $(n=8)$, alaninaminotrasferase $(n=37)$, a decreased level of serum iron $(n=65)$.

All laboratory tests were in the range of reference values for patients in the stage of induction and the maintenance of UC remission.

We found a dysbiotic relationship between protective and aggressive bacterial species in patients with $\mathrm{UC}$ in the active stage and in the stage of induction of UC remission: the increase of Escherichia coli, lactose-negative strains $(\mathrm{n}=57$; $\left.10^{5} / \mathrm{g}\right)$, Proteus spp. $\left(\mathrm{n}=45 ; 10^{5} / \mathrm{g}\right)$, Enterococcus spp. $\left(\mathrm{n}=42 ; 10^{4}\right.$ $6 / \mathrm{g})$, Staphylococcus spp. $\left(\mathrm{n}=50,10^{5-6} / \mathrm{g}\right)$, Streptococcus spp. $\left(\mathrm{n}=42 ; 10^{5-6} / \mathrm{g}\right)$, Bacteroides spp. $\left(\mathrm{n}=55 ; 10^{4-6} / \mathrm{g}\right)$, Clostridium spp. $\left(\mathrm{n}=38 ; 10^{4} / \mathrm{g}\right)$ and the decrease of Bifidobacterium spp. $\left(\mathrm{n}=63 ; 10^{5} / \mathrm{g}\right)$, Lactobacterium spp. $\left(\mathrm{n}=63 ; 10^{4-6} / \mathrm{g}\right)$ in stool culture. 
Table 2.

Histological characteristics of ulcerative colitis

\begin{tabular}{|c|c|c|}
\hline \multicolumn{2}{|c|}{$\begin{array}{c}\text { The characteristic findings at ileocolonoscopy } \\
\text { (Truelove - Witts' criteria, Schroeder classification, histological characteristics) }\end{array}$} & $\mathrm{n}$ \\
\hline Mild activity of $\mathrm{UC}^{2}$ (grade 1 ) & $\begin{array}{l}\text { Erythema, decreased vascular pattern, mild friability } \\
\text { Basal plasmacytosis, the inflammatory infiltrate in the lamina propria, absent } \\
\text { crypt architectural distortion }\end{array}$ & 39 \\
\hline Moderate activity of UC (grade 2) & $\begin{array}{l}\text { Marked erythema, absent vascular pattern, friability, erosions } \\
\text { Basal plasmacytosis or subcryptal, heavy, diffuse transmucosal lamina propria } \\
\text { cell increase and widespread crypt architectural distortion }\end{array}$ & 26 \\
\hline Moderate activity of UC (grade 2) & $\begin{array}{l}\text { Marked erythema, absent vascular pattern, friability, erosions } \\
\text { Basal plasmacytosis or subcryptal, heavy, diffuse transmucosal lamina propria } \\
\text { cell increase and widespread crypt architectural distortion }\end{array}$ & 13 \\
\hline \multicolumn{2}{|r|}{ Maintenance of remission } & 65 \\
\hline
\end{tabular}

All these changes correlate with different expressions of peptides and proteins in damaged and undamaged colon mucosa in patients with UC in the active stage and in healthy persons (Table 3). Molecules of peptides and proteins were seen to interact among themselves and with other molecules as participants in universal pathways in patients with UC in the active stage: cytokine, oxidative stress, Klotho, STATJAK signaling pathway, PPAR $\gamma$, TLR, NF-kB, $\beta$-defensin, INK4 tumor suppressor proteins pathway, MUC1-mediated signaling pathways. Bioinformatics analysis revealed the presence of molecules that are the participants in the universal pathways of $\mathrm{UC}$ in the active stage, and the molecular interactions involved.

Table 3.

Qualitative profile of peptides and proteins in colon mucosa

\begin{tabular}{|l|c|c|c|c|c|}
\hline Protein name & $\begin{array}{c}\text { MW } \\
(\mathrm{Da})\end{array}$ & $\mathrm{pI}$ & $\begin{array}{c}\mathrm{CG} \\
(\mathrm{n}=30)\end{array}$ & $\begin{array}{c}\text { UC } \\
(\text { active stage })\end{array}$ & P-level \\
\hline IL-2 & 17628 & 7.6 & 2 & 22 & 0.005 \\
\hline RBP4 & 23010 & 5.4 & 1 & 7 & 0.428 \\
\hline SMAD2 & 48081 & 6.1 & 2 & 11 & 0.096 \\
\hline HSP47 & 70052 & 9.0 & 2 & 13 & 0.058 \\
\hline HSP27 & 27000 & 6.12 & 1 & 9 & 0.162 \\
\hline HSP2 & 90000 & 5.1 & 1 & 9 & 0,162 \\
\hline TNF- $\alpha$ & 25644 & 6.4 & 2 & 24 & 0.002 \\
\hline KNG1 & 71957 & 4.8 & 1 & 10 & 0.164 \\
\hline APOC3 & 10852 & 4.6 & 1 & 15 & 0.018 \\
\hline NF-kB & 105356 & 5.5 & 2 & 25 & 0.001 \\
\hline RTKs & 104000 & 6.96 & 1 & 13 & 0.058 \\
\hline PPAR $\gamma$ & 57620 & 5.78 & 12 & 9 & 0.007 \\
\hline IL-6 & 23718 & 6.17 & 1 & 12 & 0.028 \\
\hline IL-8 & 11098 & 9.1 & 2 & 13 & 0.133 \\
\hline IL-12A & 24874 & 8.4 & 1 & 7 & 0.428 \\
\hline IL-1 3 & 30748 & 6.1 & 1 & 6 & 0.426 \\
\hline CASP8 & 55391 & 5.12 & 2 & 9 & 0.493 \\
\hline CASP10 & 58951 & 5.97 & 2 & 10 & 0.328 \\
\hline H 3 D-1 & 7420 & 4.1 & 16 & 3 & 0.000 \\
\hline CFTR & 168142 & 8.91 & 13 & 1 & 0.000 \\
\hline PHB & 29804 & 9.8 & 12 & 2 & 0.000 \\
\hline
\end{tabular}

pI-isoelectric point; $P$-value between groups based on Fisher's Exact Test

\section{Discussion}

We identified following functional groups of peptides and proteins in molecular patterns of bioptates of colon mucosa in UC patients: peptides and proteins regulating the barrier function of colon mucosa; proteins-participants of specific metabolism in epitheliocytes and endocrinocytes; proteins of the fibrosis in colon mucosa; proteins regulating cell cycle, oncogenesis, proteolysis in cell, hormones processing, angiogenesis, coagulation factors; proteins of free radical oxidation and antioxidant system; proteins regulating the receptor activity of epitheliocytes and immune cells; structural proteins of colon mucosa; transcription and translation factors regulating the activity of cell nucleus, regulators of protein folding; transport proteins; proteins-enzyms of detoxification. Below we have provided the functional activity of some of them.

SMAD family member 2 (SMAD2) activates the transcription of TFG1 $\beta$, which increases the activity of Rho/ ROCK signaling pathway in fibroblasts of colon submucosa that leads to specific regulation of the $\mathrm{CCN} 2$ gene in cells and the development of fibrosis in colon submucosa in UC patients. The stimulation of the expression of apoC-III in affected colon mucosa in $\mathrm{UC}$ is associated with the activation of the FOXO1 signaling pathway that supports inflammatory processes in colon mucosa.

The second small heat shock protein (HSP2) controls the apoptosis of colonocytes and immune response in damaged colon mucosa through expression of Bcl-2 and IL-17; HSP2 is also responsible for the mucosa resistance to therapeutic strategies. Anti-apoptotic functions of HSP27 are possible through the interaction with DAXX7, the activation of Akt and the inhibition of the apoptosis. HSP47 interacts with collagen I, II, III, IV and V types, which contributes to the launch of autoimmune process in UC.

Caspase 8 protects colonpcytes from TNF $\alpha$-induced cell death through a necroptosis mechanism via the blockade of the RIP3 expression. The expression of prohibitin maintains 
optimal activity of the electronic transport chain through the activity of transcription factor STAT3 and the decrease in the $\mathrm{TNF} \alpha$ expression.

Significant decrease of the PPAR $\gamma$ expression promotes the activation of STAT and AP-1 signaling pathways, which promotes an increase in the synthesis of IL-2,6,8,12, TNF $\alpha$, matrix metalloproteinases, the activity of immune and inflamation processes in colon mucosa. A significant increase in the NF-kB expression in colon mucosa is associated with the activation of TNF $\alpha$ and IL-1, which promotes the increase of immune processes in colon mucosa.

The molecular interactions of $\beta$-defensin- 1 are presented in Figure 1. The reduction of the $\beta$-defensin- 1 expression in cells of colon mucosa is accompanied by increased expression of CCR6, which promotes the formation of inflammatory infiltrates in coloc submucosa in UC.

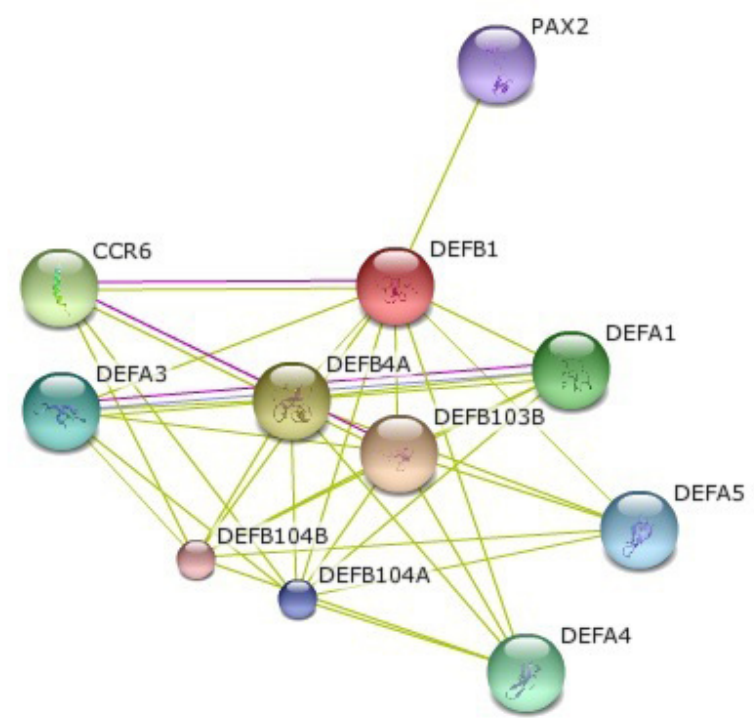

Figure 1. Molecular interactions of $\beta$-defensin -1 (STRING 10.0 database)

DEFB1, defensin beta 1; DEFA4, defensin alpha 4, corticostatin; DEFB4A, defensin, beta 4A; DEFA3, defensin alpha 3, neutrophil-specific; DEFA5, defensin alpha 5, Paneth cellspecific; DEFA6, defensin alpha 6, Paneth cell-specific; CCR6, chemokine (C-C motif) receptor 6; ALB, albumin; $M Y C, v$-myc avian myelocytomatosis viral oncogene homolog, $\boldsymbol{C A M P}$, cathelicidin antimicrobial peptide; PAX2, paired box 2.

In conclusion, we identified potentially new molecular markers of the development of UC. This information may provide new avenues for the development of novel diagnostic tests for UC.

\section{Competing interests}

The authors declare that they have no competing interests.

\section{References}

1. Lakatos PL. Recent trends in the epidemiology of inflammatory bowel diseases: up or down? World J Gastroenterol. 2006;12(38):6102-8.

2. Büsch K, Ludvigsson JF, Ekström-Smedby K, Ekbom A, Askling J, Neovius M. Nationwide prevalence of inflammatory bowel disease in Sweden: a population-based register study. Aliment Pharmacol Ther. 2014;39(1):57-68.

3. Garrett WS, Gordon JJ, Glimcher LH. Homeostasis and inflammation in the intestine. Cell. 2010;140(6):859-70.

4. Andersen V, Christensen J, Ernst A, Jacobsen BA, Tjønneland A, Krarup HB, et al. Polymorphisms in NF-kB, PXR, LXR, PPAR $\gamma$ and risk of inflammatory bowel disease. World J. Gastroenterol. 2011;17(2):197-206.

5. Andersen V, Nimmo E, Krarup HB, Drummond $H$, Christensen J, Ho GT, et al. Cyclooxygenase-2 (COX-2) polymorphisms and risk of inflammatory bowel disease in a Scottish and Danish case-control study. Inflamm Bowel Dis. 2011;17(4):937-46.

6. Comelli EM, Lariani S, Zwahlen MC, Fotopoulos G, Holzwarth JA, Cherbut C, et al. Biomarkers of human gastrointestinal tract regions. Mamm Genome. 2009;20(8):516-27.

7. Li X, Conklin L, Alex P. New serological biomarkers of inflammatory bowel disease. World J. Gastroenterol. 2008;14(33):5115-24.

8. Satsangi J, Silverberg MS, Vermeire S, Colombel JF. The Montreal classification of inflammatory bowel disease: controversies, consensus, and implications. Gut. 2006;55(6):749-53.

9. Truelove SC, Witts LJ. Cortisone in ulcerative colitis; final report on a therapeutic trial. Br Med J. 1955;2(4947):1041-8. 10. D'Haens G, Sandborn WJ, Feagan BG, Geboes K, Hanauer $\mathrm{SB}$, Irvine EJ, et al. A review of activity indices and efficacy end points for clinical trials of medical therapy in adults with ulcerative colitis. Gastroenterology. 2007;132(2):763-86.

11. Dignass A, Eliakim R, Magro F, Maaser C, Chowers Y, Geboes K, et al. Second European evidence-based consensus on the diagnosis and management of ulcerative colitis. Part 1: Definitions and diagnosis. J Crohns Colitis. 2012; 6(10):965-90. 12. Schroeder KW, Tremaine WJ, Ilstrup DM. Coated oral 5-aminosalicylic acid therapy for mildly to moderately active ulcerative colitis. A randomized study. N Engl J Med. 1987;317(26):1625-9.

13. Travis SP, Schnell D, Krzeski P, Abreu MT, Altman DG, Colombel JF, et al. Developing an instrument to assess the endoscopic severity of ulcerative colitis: the Ulcerative Colitis Endoscopic Index of Severity (UCEIS). Gut. 2012;61(4):535-42. 